\title{
Valorisation of Food Waste in Hong Kong for the Sustainable Production of Chemicals and Materials
}

\section{Carol Sze Ki Lin*}

School of Energy and Environment, City University of Hong Kong, 2/F, Harbour View 2, 16 Science, Park East Avenue, Hong Kong Science, Hong Kong

Food waste, one of the largest potions of municipal solid waste, is a global problem. Every year nearly 1.3 billion tons of food trash are dumped in landfills and otherwise wasted around the world. As the world's most densely populated metropolis, the food waste issue in Hong Kong is more severe than other Asian developed jurisdictions such as Singapore, South Korea and Taiwan. In Hong Kong, where people love to eat out, leftover food takes up much of the limited space in city landfills. The amount of food discarded by the hospitality industry has more than doubled in the past five years and about a third of more than nine-thousand tons of solid waste dumped in the city's landfills each day is leftover food! It is most likely that the existing landfills in Hong Kong will be full before 2020 according to local Waste Disposal Plan [1]. Severe environmental problems could be caused as well.

To solve the problems, the utilization of food waste as the renewable feedstock in biorefinery for chemicals and energy production would be a promising option. The nutrients contained within food waste can be converted by microorganisms into desired products, such as biofuels [2], functional chemicals [3] and monomers of bioplastics [4]. The goal of our research group has always been to facilitate the transformative technology and alleviate the pressure from food waste crisis in Hong Kong. Sponsored by a number of local industries including Starbucks Hong Kong, we have obtained now some exciting results. Using waste bread as the sole nutrient source, we developed a strategy for the fermentative production of a high-value product, namely succinic acid (SA), by the anaerobic bacteria Actinobacillus succinogenes. SA has topped at U.S. Department of Energy list of 12 key materials that can be produced from sugars and has been regarded as an alternative to the current non-sustainable petrochemical route. A high yield of $47.3 \mathrm{~g} / \mathrm{L}$ of SA has been obtained by us and some of our findings are published [5]. Hopefully, it can be adopted by the Hong Kong Government as part of their strategy for tackling the food waste problem and for the environmentally friendly production of alternative platform chemicals.

\section{References}

1. An overview on challenges for waste reduction and management in Hong Kong

2. Garcia-Pena El, Parameswaran P, Kang DW, Canul-Chan M, KrajmalnikBrown R (2011) Anaerobic digestion and co-digestion processes of vegetable and fruit residues: process and microbial ecology. Bioresour Technol 102: 9447-9455.

3. Bozell JJ, Petersen GR (2010) Technology development for the production of biobased products from biorefinery carbohydrates-the US Department of Energy's Top 10 revisited. Green Chem 12: 539-554.

4. Tokiwa Y, Caiabia BP (2008) Biological production of functional chemicals from renewable resources. Can J Chem 86: 548-555.

5. Leung CC, Cheng SY, Zhang YZ, Lam KF, Lin SK (2012) Utilization of waste bread for fermentative succinic acid production. Biochem Eng J 65: 10-15.
*Corresponding author: Carol Sze Ki Lin, School of Energy and Environment, City University of Hong Kong, 2/F, Harbour View 2, 16 Science, Park East Avenue, Hong Kong Science, Hong Kong, Tel: 852-3442-7497; Fax: 852-2319-5927; E-mail: carollin@cityu.edu.hk

Received August 10, 2012; Accepted August 10, 2012; Published August 11 2012

Citation: Ki Lin CS (2012) Valorisation of Food Waste in Hong Kong for the Sustainable Production of Chemicals and Materials. J Food Process Techno 3:e109. doi:10.4172/2157-7110.1000e109

Copyright: ( $2012 \mathrm{Ki}$ Lin CS. This is an open-access article distributed under the terms of the Creative Commons Attribution License, which permits unrestricted use, distribution, and reproduction in any medium, provided the original author and source are credited. 